欧州（EU）における公的な患者向け医薬品情報とユーザーテスト

\author{
山本美智子, ${ }^{* a}$ 土 肥 弘 久, ${ }^{a}$ 古川 綾 $^{b}$
}

\title{
Drug Information for Patients (Package Leaflets), and User Testing in EU
}

\author{
Michiko Yamamoto, ${ }^{*, a}$ Hirohisa Doi, ${ }^{a}$ and Aya Furukawa ${ }^{b}$ \\ ${ }^{a}$ Showa Pharmaceutical University; 3-3165 Higashi-Tamagawagakuen, Machida, Tokyo 194-8543, Japan: and \\ ${ }^{b}$ TAMA University of Medical Risk Management Center, 4-1-1 Hijirigaoka, Tama, Tokyo 206-0022, Japan.
}

(Received September 20, 2014)

\begin{abstract}
Patients and consumers have desired high quality drug information in their pharmacotherapy, and are entitled to receive it. It is desirable that the information should be aimed at shared decision-making between patients and healthcare professionals about medications. The quality of drug information available to patients should also be assured. With an aim to improve the quality of "Drug Guide for Patients", we investigated Patient Information Leaflets (PILs) which are approved by the Medicines and Healthcare Products Regulatory Agency (MHRA) in the United Kingdom (UK) with regard to the criteria of development and user testing for assuring the quality of the PILs. In the European Union (EU), these are called Package Leaflets (PLs). PILs have been a legal requirement in the UK since 1999 for all medications. The user testing of PILs has been implemented as evidence since 2005 so that people can rely on the information provided in the leaflet. Execution of PILs which follow the guidance of the user testing, according to the guidance of this user testing, would reflect the views of patients. Here, we introduce the development process and implementation of user testing of PILs. In terms of readability, accessibility and understandability of drug information for patients, we need to discuss involving the public in decisions on how its quality should be assured and how it can be made easily be comprehensible for patients, in order to make effective use of "Drug Guide for Patients" in the future in Japan.
\end{abstract}

Key words_—Drug Guide for Patients; user testing; patient information leaflet; package leaflet (PL); drug information for patient; risk communication

\section{1.はじめに}

国内における患者向けの医療用医薬品の情報とし

て，厚生労働省から「患者向医薬品ガイド」が提供 されている. 同ガイドは，平成 17 年 6 月 30 日厚生 労働省医薬食品局長通知に基づき，患者等が医療用 医薬品を正しく理解し重篤な副作用の早期発見等を 促す目的で，添付文書の内容に準拠し，高校生程度 の者が理解できるよう作成された患者向けの資材で ある。厚生労働省は平成 24 年 4 月に公表した「医 薬品リスク管理計画指針」の中で，「患者向医薬品 ガイド」は通常のリスク最小化活動と位置付けた. しかし，薬剤師向けのアンケート調査 ${ }^{1)}$ 等の結果か

$a$ 昭和薬科大学 (テ194-8543 東京都町田市東玉川学園 3-3165） b多摩大学医療リスクマネジメントセンター (†206-0022 東京都多摩市聖ヶ丘 4-1-1)

*e-mail: m-yamamoto@ac.shoyaku.ac.jp

本総説は, 日本薬学会第 134 年会シンポジウムS36 で 発表した内容を中心に記述したものである。
ら, 現状では「患者向医薬品ガイド」の認知度は半 数以下に留まっており, 内容についても改善が必要 なことが明らかになった。

今回，「患者向医薬品ガイド」の改善を目的に， 公的な患者向け情報, 特に英国における公的な患者 向け情報やユーザーテストについて調査を行ったの で紹介する. ${ }^{2-5)}$

\section{2. 患者向け医薬品情報に必要なこと}

患者向けの医薬品情報は, 患者が医薬品を安全に 服用し，医薬品から得られるべネフィットを最大 化・リスクを最小化するために必要である。患者は 薬物治療において質のよい医薬品情報を望んでお り，またそれを得る権利を併せ持っている．医療に おける患者と医療従事者の関係はパターナリズムか らインフォームド・コンセント, さらには, shared decision making（必要な情報を共有した上での意 思決定）へ変わってきている（Fig. 1)。服薬に関 して言えば, 患者が処方箋の指示に従って薬の服用 


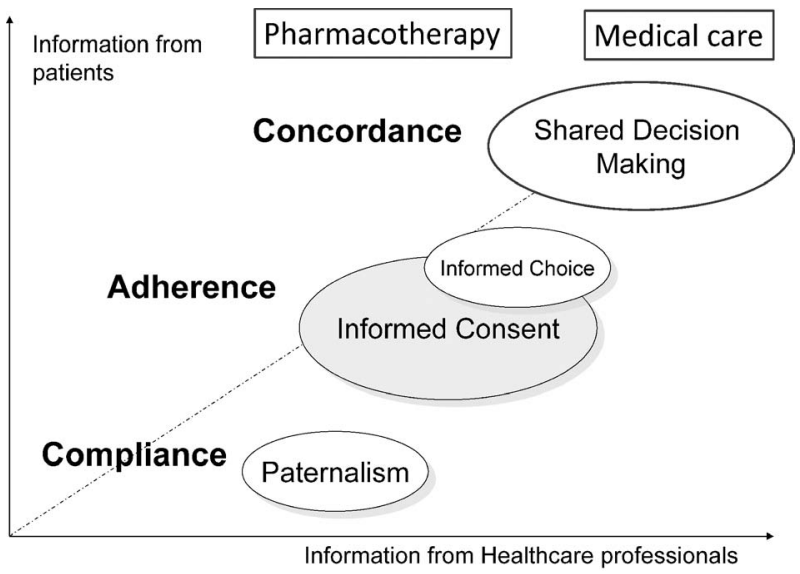

Fig. 1. Shared Decision Making and Concordance in Medication

を守るといったコンプライアンス（compliance）か ら，服薬を守るという意味では変わらないが参加や 自律性を重んじたアドヒアランス (adhearance), そして患者の考えを尊重した話し合いの後に患者と 医療従事者が到達する合意としてコンコーダンス (concordance) という言葉が用いられる。いずれに しても，医師と患者が，パートナーシップに基づき お互いの専門性を尊重し意思決定のプロセスを重視 することが求められる，そのような意思決定ができ るような情報ソースとしての医薬品情報が患者に とって必須となる.

基本的な前提として，患者が医薬品を服用する意 義と正しい服用方法を理解することは, コンプライ アンスの向上，治療効果の向上に不可欠である。ま た, 医薬品の副作用などのリスクの情報提供は公衆 衛生に対する潜在的なインパクトを有するため，患 者へのコミュニケーションには特に注意が求められ る.

このようなことを考慮した医薬品情報を患者に提 供するためには，その情報の質が担保されるしくみ が必要となる. 患者が必要な情報をすぐに見い出せ ること, 患者が必要な行動を想起できることが明確 となるように記載することが重要である。そのため に, European Union（EU）では患者の意見や視点 を反映したユーザーテストが取り入れられることに なった.

\section{EU における公的な患者向け医薬品情報}

3-1. PIL/PL の成り立ち EUにおける公的 な患者向医薬品情報書として, package leaflets

（PLs）がある，なお，同様のものであるが，英国 では patient information leaflets（PILs）と呼ばれ ている.

英国では，PIL の作成は 1999 年からすべての医 薬品に対して法的に要求されている. PIL は, 読み 手にとつて利用し易く理解し得る包括的な情報を盛 り込むことと定められている。製薬企業が策定した PIL は, 医薬品の承認要件の 1 つとして必要なもの で，規制当局のレビューを受ける，適切な情報が患 者の decision-making をサポートするとの考えから， 2005 年 Medicines and Healthcare Products Regulatory Agency (MHRA) と Committee on Safety of Medicine（CSM）との共同で，患者向け情報作成 の基本的な指針として “Always Read the LeafletGetting the best information with every medicine (ARTL)”6) が策定された.

PIL のレビュー等は MHRA の Patient Information Quality Unit (PIQU) ${ }^{7)}$ という専門のユニット が担当し，スタッフは全員で 5 名である. MHRA は 10 の部局に分かれており，PIQU はその 1 つで ある医薬品監視及びリスクマネジメント部門 (Vigilance and Risk Management of Medicines; VRMM）の中にある.PIQU は，審查部門とも連 携し承認から市販後までの一連の患者向け・一般向 け情報に関与している，英国では，患者は医師から 処方箋をもらい，それを薬局に持っていくと，医薬 品は箱単位で提供される。箱毎に PIL が梱包され ており，その状態で患者に手渡されるので，かなら ず患者の手元に PIL が届くしくみになっている.

3-2. PIL の概要ＰIL は欧州指令より規定さ れている.PIL に記載される項目は 6 項目である (Table 1)。また, PL/PIL の特徵について Table 2 に記し，患者向医薬品ガイドや米国 Food and Drug Administration（FDA）が承認している患者向け情 報（Medication Guides）の特徵も合わせて記載し

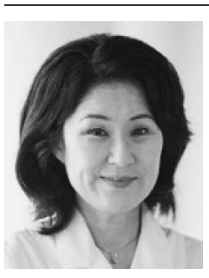

山本美智子
昭和薬科大学医療薬学教育センター 長・教授. 1975 年熊本大学薬学部卒 業. 東京医科歯科大学院博士号取得. ドイツ Albert Ludwigs 大学, 国立医薬 品食品衛生研究所, 独医薬品医療機器 総合機構, 鈴鹿医療科学大学薬学部を 経て 2013 年より現職. 医薬品の安全性 評価, 情報リテラシー, リスクコミュ ニケーションの研究に取り組む. 
Table 1. Order and Content of the Information in Patient Information Leaflets

\begin{tabular}{|c|c|}
\hline $\begin{array}{l}\text { Identification of the } \\
\text { medicine }\end{array}$ & $\begin{array}{l}\text { The name, the active substance(s), } \\
\text { the pharmaceutical form, strength of } \\
\text { the product should be stated. }\end{array}$ \\
\hline $\begin{array}{l}\text { Therapeutic indica- } \\
\text { tions }\end{array}$ & $\begin{array}{l}\text { The conditions for which the medicine } \\
\text { is authorised must be listed. This sec- } \\
\text { tion should include any benefit infor- } \\
\text { mation considered appropriate. }\end{array}$ \\
\hline $\begin{array}{l}\text { Information neces- } \\
\text { sary before taking } \\
\text { the medicine }\end{array}$ & $\begin{array}{l}\text { Situations where the medicine should } \\
\text { not be used, any precautions, warn- } \\
\text { ings, interactions with other medi- } \\
\text { cines or foods, information for spe- } \\
\text { cial groups of patients (pregnant or } \\
\text { nursing mothers), and any effects the } \\
\text { medicine may have on the patient's } \\
\text { ability to drive. }\end{array}$ \\
\hline Dosage & $\begin{array}{l}\text { How to take or use the medicine in- } \\
\text { cluding both the route and method of } \\
\text { administration, how often it should } \\
\text { be given, how long the course of treat- } \\
\text { ment will last, what to do if a dose is } \\
\text { missed and if relevant what do in the } \\
\text { event of an overdose and the risk of } \\
\text { withdrawal effects. }\end{array}$ \\
\hline $\begin{array}{l}\text { Description of side } \\
\text { effects }\end{array}$ & $\begin{array}{l}\text { All the effects which may occur under } \\
\text { normal use of the medicine and what } \\
\text { action the patient should take if any } \\
\text { of these occur. These should be listed } \\
\text { by seriousness and then by frequency. }\end{array}$ \\
\hline $\begin{array}{l}\text { Additional informa- } \\
\text { tion }\end{array}$ & $\begin{array}{l}\text { This covers information on excipient } \\
\text { details, a description of the product, } \\
\text { registered pack sizes, storage condi- } \\
\text { tions, name and address of the MAH } \\
\text { and manufacturer. }\end{array}$ \\
\hline
\end{tabular}

Accordance with Article 59(1) of Council Directive 2001/83/EC

比較した. ${ }^{8)} \mathrm{PIL}$ の作成に関し考慮すべき主要な点 として，以下のことが挙げられている. ${ }^{9}$

- 製品の安全な使用のために，患者向けにキー メッセージを作成すること.

- 医療者向けの添付文書に相当する Summaries of Product Characteristics（SPC）に準拠 すること.

- 難解な用語や医学専門用語は使用しないこと.

- すべての情報は, lay language を用い, 文章 は短くすること.

- 副作用の表記に器官別分類の名称は用いない.

・ 副作用は，患者がいつどのような行動をとる べきか理解できるよう重篤度で分類すること.

・ デザイン, レイアウトを考慮すること.

PIL は Quality Review of Documents (QRD human product-information template version 8.3) ${ }^{10)}$ に 準拠する必要がある。 また，Quality criteria for PILs ${ }^{11)}$ には PIL 作成に関する評価の指標が示され
ている。

$$
\text { 4. PIL のユーザーテスト }
$$

4-1. ユーザーテストの経緯ＰIL の作成前 に，その医薬品にとって安全に使用するためのキー メッセージとして何が必要かを決めておく必要があ る。このキーメッセージは PIL の冒頭に示される ことが多く，読み手にとって注目すべき情報が何か を把握することが容易になる，安全性に関するキー メッセージを確定するには，ユーザーテストを用い て検証する。

PL の患者の理解度を診断するためのユーザーテ ストは，1990 年代初頭にオーストラリアで開発さ れ，Slees らによる「有用性ガイドライン」に引き 継がれた. ${ }^{12)} 1999$ 年, European Commission (EC) によって「読み易さに関するガイドライン」13)の中 でユーザーテストが推奨された。 PL に関しては, 欧州指令 2001/83/EC（のちに指令 2004/27/ECに 変更）により患者に正しく理解される医薬品情報を 提供するために，2005 年に PL のユーザーテスト が義務づけられた。 ${ }^{13)}$ 英国の医薬品の規制機関であ る MHRA も，同指令に基づき，PIL に対し同年に ユーザーテストを義務付けた，MHRA は，PIL に ついてユーザーテストを義務付けるガイドライン (Guidance on the user testing of patient information leaflets) ${ }^{14)}$ を発行し，その中で 2005 年 7 月 1 日以降 に発売される医薬品の PIL はユーザーテストを実 施し，MHRA のレビューと承認を受けなければな らないとした。また，2005 年 7 月 1 日以前に承認 されている医薬品の PIL は，2008 年 7 月 1 日まで にユーザーテストを実施し，更新することが求めら れた。これにより製薬企業は，ユーザーテストを実 施するための手順を決め，テスト計画書，結果報告 書, 最終の PIL を MHRA に提出することとなっ た。ユーザーテストについて追加のアドバイスとし て, Further Guidance ${ }^{15)}$ を発行した。この中で, 質 の高い情報は 2 つの要素（情報のデザインとレイア ウト, 内容）に依存し，いずれも等しく重要で, PIL 作成過程で十分に考慮すべきと指摘している.

4-2. PIL 作成におけるユーザーテストの方針 ユーザーテストは，患者の安全性確保のために実 施される PIL 作成におけるプロセスの 1 つである.

PIL が多くの人にとって，安全な使用と正しい治療 の決定につながるよう，そのエビデンスを提供する 
Table 2. Comparison of Authorized Medicine Leaflets for Patients in Japan, EU and USA

\begin{tabular}{|c|c|c|c|}
\hline Regulatory Agency & $\begin{array}{l}\text { Japan (Ministry of Health, Labour } \\
\text { and Welfare) }\end{array}$ & $\begin{array}{l}\text { 1. EU (European Medicines Agen- } \\
\text { cy; EMA), 2. UK (Medicines and } \\
\text { Healthcare Products Regulatory } \\
\text { Agency; MHRA) }\end{array}$ & $\begin{array}{l}\text { USA (Food and Drug Administra- } \\
\text { tion; FDA) }\end{array}$ \\
\hline Name & Drug Guide for Patients & $\begin{array}{l}\text { 1. Package Leaflets (PLs) } \\
\text { 2. Patient Information Leaflets (PILs) }\end{array}$ & Medication Guides \\
\hline Objective & $\begin{array}{l}\text { Encourage patients } \\
\text { - to understand medicines properly } \\
\text { - to detect adverse reactions early }\end{array}$ & $\begin{array}{l}\text { - Help patients participate fully in } \\
\text { concordant decision-making } \\
\text { - Facilitate safe use of the medicine }\end{array}$ & $\begin{array}{l}\text { Help patients avoid serious adverse } \\
\text { events }\end{array}$ \\
\hline Literacy skills & equivalent to 14 years old & equivalent to 11 years old & equivalent to 11 years old \\
\hline Targeted medicines & $\begin{array}{l}\text { 1. Prescribed drugs with informa- } \\
\text { tion calling for proper use by } \\
\text { patients } \\
\text { 2. Risk Management Plan (RMP) } \\
\text { components }\end{array}$ & $\begin{array}{l}\text { 1. All medicines (since 1999) } \\
\text { 2. Risk Evaluation and Mitigation } \\
\text { Strategy (REMS) componets }\end{array}$ & $\begin{array}{l}\text { 1. When the Agency determines that: } \\
\text { - certain information is necessary } \\
\text { to prevent serious adverse effects } \\
\text { - patient decision-making should be } \\
\text { informed by information about a } \\
\text { known serious side effect with a } \\
\text { product, or } \\
\text { - patient adherence to directions } \\
\text { for the use of a product are essen- } \\
\text { tial to its effectiveness. } \\
\text { 2. Risk Evaluation and Mitigation } \\
\text { Strategy (REMS) components }\end{array}$ \\
\hline Provided mode & Web $\left(\right.$ PMDA $\left.^{*}\right)$ only & $\begin{array}{l}\text { 1. Printed materials (package insert) } \\
\text { 2. Web (EMA, MHRA, eMC) }\end{array}$ & $\begin{array}{l}\text { 1. Paper handouts } \\
\text { 2. Web (FDA) }\end{array}$ \\
\hline $\begin{array}{l}\text { Description of Ad- } \\
\text { verse rections }\end{array}$ & $\begin{array}{l}\text { Serious adverse reactions } \\
\text { (Not required to describe occur- } \\
\text { rence frequency) }\end{array}$ & $\begin{array}{l}\text { Serious side effects and Common } \\
\text { side effects } \\
\text { (listed by seriousness and then by } \\
\text { frequency.) }\end{array}$ & $\begin{array}{l}\text { Serious side effects and Common } \\
\text { side effects } \\
\text { (Not required to describe occur- } \\
\text { rence frequency) }\end{array}$ \\
\hline Table of contents & No & Yes & No \\
\hline
\end{tabular}

*Pharmaceuticals and Medical Devices Agency

ために行われるテストである．PIL 作成における ユーザーテストの意義として以下のことが挙げられ る.

- 医薬品について安全で正確な決断ができるよ うに，多くの患者によって PIL が用いられ るというエビデンスを提供すること.

- PIL 開発のプロセスの中心に患者を置くこと.

- 最も重要な情報は何かをテストの前に明白に 決定する（例：用量，重大な副作用や警告な ど).

- 当該医薬品のリーフレットに頼るような特別 な対象患者に反映すること.

・信頼のおけるエビデンスを提出すること（例 えば，明白なプロトコールに対しテスト被験 者から集められたデータであること).

ロ テスト被験者が情報を見い出し, 適切に使う ことができるというエビデンスを提出するこ と.
4-3. ユーザーテストの実施プロセスユー ザーテストが必要となる場合は, 新規医薬品, Prescription Only Medicine (POM) から Pharmacy medicines（P）に切り替わるとき，特別に安全 性に関する懸念事項がある場合, 法的要件に変更が あった場合などである.

ユーザーテストのガイドライン並びにユーザーテ スト実施機関からのヒアリング結果より，そのプロ セスを Fig. 2 に示した.

1）テスト用 PIL の準備

PIL を作成する製薬企業はユーザーテストに用い る PIL のドラフトを用意する，デザインやレイア ウト並びに文章の表現などについて確認し, 必要に 応じて修正したものとする.

2) テスト形式

テストは, 被験者とインタビュアーとの $1: 1$ の 対面のインタビュー方式で行う. 


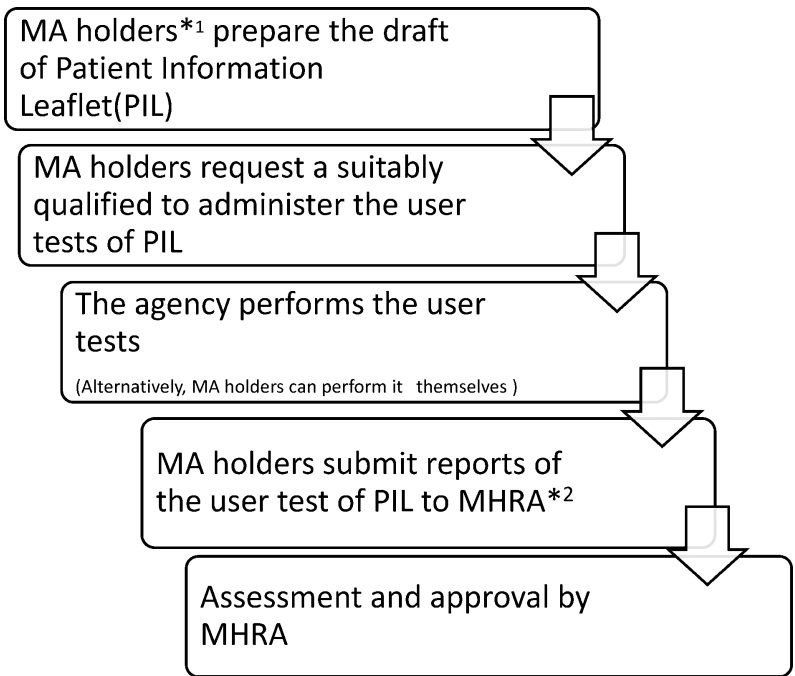

Fig. 2. Process of Patient Information Leaflets (PILs) Development Leading to Approval

${ }^{*}$ Marketing Authorization holders. ${ }^{*}$ Medicines and Healthcare Products Regulatory Agency.

\section{3）被験者の特徵と条件}

ガイドライン14)では，被験者について以下のよう に示している，当該医薬品を服用すると予想される 集団を反映した，少なくとも 20 人で，その内訳は 以下の通りである.

・医薬品を服用することがイメージできる広範な 異なったタイプの人々.

・もし対象医薬品が稀な疾患の適応であれば，そ の疾患の患者を含むことが望ましい。

・特別な年齢層（若い方，高齢者など）.

・仕事で文書を使用しない人々や文書の理解が難 しいと判断される人々。

・除外となるのは，医師，薬剤師，看護師，その 他の医療従事者, 以前に当該医薬品を服用した 患者や最近服用している患者.

・リーフレットを読むのに慣れて被験者として適 さなくなるのを回避するために，一度テストに 参加した人は，次に参加するまでに 6 力月以上 はブランクをおく，被験者に関する情報は報告 書に記載される。

資格と職業についても，様々な種類の人を組み入 れる，例えば，大卒者と非大卒者などである，但 し，看護師，医師，薬剤師など日常的にリーフレッ トを読む機会がある人は除外する。

4）被験者パネル

ユーザーテストの実施機関では，通常被験者候補
のパネルを有し，年齢，教育水準などに関して様々 なバックグラウンドの人を集めている．診療所，母 子教室，老人クラブなどを通して，地域住民に協力 を呼びかけたり，又は新聞広告などで募った人々の 名前，住所，年齢，資格，職業を記録して，データ ベース化している.

5）インタビュアーの要件

ガイドライン14)では，インタビューは優れたイン タビュー能力, 観察能力, 聴取能力を持った経験豊 富なインタビュアーにより実施するとされている. ヒアリングを行った実施機関では，インタビュアー に特別な資格を求めてはいないが，テストの前に, 社内研修を受講するシステムをとつていた．被験者 の中には，自分自身の読解力をテストされていると 錯覚をして緊張する人もいることを考慮し，落ち着 いた雾囲気で和やかな接し方ができることも要件と されている。

6）インタビュー内容

インタビュー内容としては, 以下のことに留意す る必要がある。

・医薬品の重大な安全性事項を適切にカバーする こと.

・質問は最小に，通常 12-15 問で十分である。も し，重大な安全性事項が懸念される場合はそれ 以上のこともある.

・一般的な事項及び医薬品に関連した特別な遵守 事項をカバーすること.

一般的な事項とは，飲み忘れ，副作用が起きた 場合の対処など.

・人々が最も不安に思う事項（副作用に関連する 内容）を盛り込むこと.

・そのままのフレーズでの答えではなく別のフ レーズで答えるようにさせること.

・リーフレットの順番ではなく，ランダムに質問 が来るようにすること.

また，重篤な副作用に関する質問を避けるとその テストは信頼性に欠けると指摘している，例えば, 副作用に関する質問を 3 問行う場合は，続けて行わ ず，他のセクションの質問を間に挟む。これによ り，「15 種の情報をすべて適切に見つけられた人 は，他の情報も同じように見つけられるだろう」と 想定している。.また，ガイドラインでは求められて いないが，これら QA 形式の質問のほか，最後に 


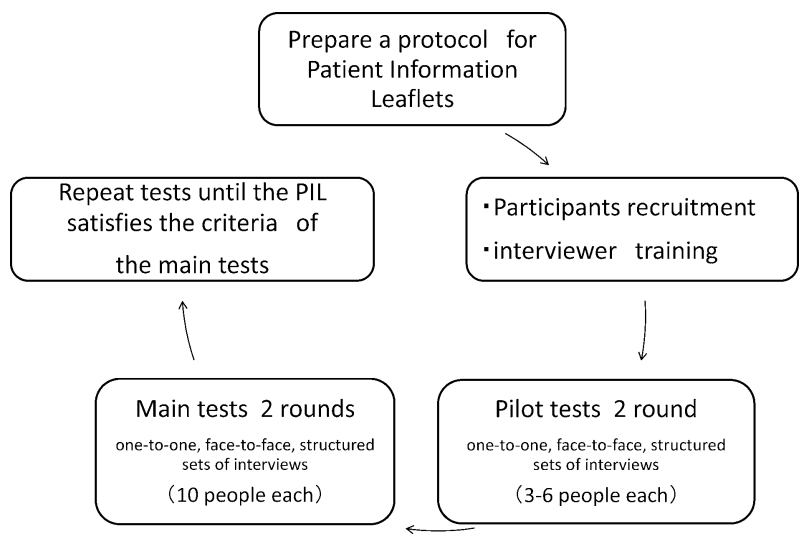

Fig. 3. Flowchart of User Testing for Patient Information Leaflets (PILs)

In order for PIL to satisfy the criteria, (1) $90 \%$ of the participants (18 out of 20 people) need to identify relevant information on the PIL and (2) $90 \%$ (16 people) of those who identified the information also comprehend the content of the information.

全体の印象を被験者に確認することが多い。リーフ レットは見易かったか，見出しは分かり易かった か，箇条書きの表記はどうだったかなど，デザイン に関する主観的な意見を求める.

7） テストの実施

本テストに先だち，3-6人を対象としたパイロッ トテストを 2 回実施する. パイロットテストの目的 は，大きな問題点を発見し，本テスト前に解決する ことであり，本テストに向けて PIL のドラフトを 修正する，その後，本テストを 2 回実施する．被験 者 10 人で 2 回行い, 合計 20 人の結果を集計する.

ユーザーテストのフローチャートを Fig. 3 に示し た.

インタビュアーは被験者に質問し，質問に対する 回答を記録するとともに，被験者がどのように PIL を扱い，情報を探すかを観察し，被験者が迷つた り，混乱したりしていないかを記録する，必要な情 報の記載箇所を指し示すことができるか, 記載事項 をおうむ返しにそのまま読むのではなく，自らの言 葉に置き換えて説明できるかも確認する．ヒアリン グを行った実施機関では, 被験者には伝えずに各質 問に時間制限を設けておき，制限時間(例えば 2 分) 以上考えても答えが返って来ない場合は，「情報を 見つけられなかつた」と記録して，次の質問に移る というように行っていた. また，インフォームド・ コンセントは“Confidentiality agreement and statement of understanding” という様式を用いて，被験 者から承諾を得ていた。

\section{8）合格基準}

テストの合格基準は，ガイドラインに定められて いる。各質問にはあらかじめ正解を準備し，被験者 の $90 \%$ が情報を見つけ出し，そのうち $90 \%$ の人が 正解できることを確認する．2 ラウンドのテストの 合計で 20 人中 16 人が正解であればテストは合格と みなされる。合格基準に至らない場合，再テストを 行い，PIL を修正しなければならない。この被験者 の $90 \%$ のちの $90 \%$ という基準は, Sless らの 1997 年の業績に負うところが大きい. ${ }^{16)}$ また, Always Read The Leaflet もこれを支持している. ${ }^{6}$

9） 報告書の作成

テスト終了後に，規制当局へ提出するための報告 書が作成される，報告書には，医薬品名，製薬企業 名，ユーザーテストの実施機関名，テスト用 PIL, テスト計画書，テスト結果に基づき PIL をどのよ うに変更したかがわかる記録，テスト結果，最終の PILが包含される.

\section{5. ユーザーテストに対する MHRA の評価}

MHRA は最終的に提出された PIL 及びユーザー テストの報告書をもって, 適正かどうか審査を行う.

MHRA は，基本的には，ユーザーテスト自体には 関与しない。PILについては，以下のような事項を チェックし評価する.

— PIL 最終版のデザイン, レイアウト, フォン トは適切か.

・ 安全性に関するキーメッセージが適切に設定 されているか.

一情報を見つけ, その対応(行動)がとれるか.

- 専門用語が使われていないか, わかり易い言 葉で書かれているか.

また，ユーザーテストの報告書については，下記 のような観点から審査を行う.

- テストのプロセス（フローチャート）が妥当 か.

- 特に安全性に関して質問は十分か.オープン クエスチョン形式が用いられているか.

- 結果はどうだつたか（約 8 割の人が理解し, どのような対応が必要かを言えて合格).

・ 被験者のコメントを読み，それが PIL に反 映されているか.

なお，同じ成分で用法違いや同じ薬効グループの 場合など，ユーザーテストのブリッジングが可能と 
している。しかし，製薬会社が異なるとブリッジン グは難しいので現実には少ない.

\section{6. おわりに}

英国では，すべての医薬品について PIL が用意 されている，また，医療用医薬品と OTC 医薬品の 情報説明書の 6 項目は全く同じである。医薬品に関 する患者向け情報については，これまで様々な試み が行われ，フォーマットが改訂されてきた. グロー バルな流れの中で，患者向け情報である PIL の重 要性の認識や社会的責任の高まりから，すべての医 薬品について作成されるに至つたＰIL の記載項目 など基本のフォーマットは決まっているが，会社そ れぞれのフォーマットを持っており，かなり自由度 があるように思われた，そのフォーマットが，患者 にとつて読み易く理解し易いものでなおかつ安全性 を確保するのに役立つものかといつたことをエビデ ンスとして示す検証プロセスがユーザーテストであ る.

このテストの導入には，かなりの年月を費やして 業界や患者団体，アカデミアとの話し合いや交渉が 持たれたようである．Raynor やKnapp らによる実 証研究も行われ，それにより患者向け情報のあり方 についてのエビデンスが構築され MHRA の方針に 影響を与えているとも言える. ${ }^{17-20)}$

既述したように英国では，患者は処方箋を医師か らもらい，それを薬局に持っていくと医薬品は箱単 位で提供される。したがって，箱毎にPIL が梱包 されており，その状態で患者に手渡されるので，か ならず患者の手元に PIL が届けられることにな る。しかし，PILがどの程度実際に活用されている かといつた調査は行われていないようだ.

現在，患者向医薬品ガイドはすべての医薬品では 作成されていない。しかし，患者向医薬品ガイド は，リスク管理計画においてリスク最小化活動の 1 つとして位置付けらており，新規医薬品については 作成対象となるため，今後の充実が期待される.

患者の安全性確保のために，国内における患者向 医薬品ガイドの利活用を進めるためには，その普及 手段や方策を考えることも必要である．内容につい ては，どのようなフォーマットが読み易く，理解し 易いのかを，まずは，ユーザーテストの手法を参考 にしながら検証していくことも 1 つの試みと言え る。実際に，パイロットとして，ストラテラ®につ
いて患者向医薬品ガイドの既存版と試作版を用いて ユーザーテストを試みたところ，情報の見つけ易さ や理解のし易さなどが指標として有用であり，ユー ザーの視点からの改善点や検討すべき点などが明ら かになった。 ${ }^{4)}$ ユーザーテストは，比較的簡便な情 報評価方法として，患者向医薬品ガイドに用いるこ とは可能であると考えられた。

各医薬品についてユーザーテストを行うことによ り，どのような安全性メッセージをどのように表記 することが適切かを検証し，患者の安全性の確保に 向けたエビデンスを実証できる意義は大きいと考え る.

謝辞本調查に協力頂いた英国 MHRA の PIQU 担当の Jan MacDonald 氏及びユーザーテス 卜実施機関である Cambridge Regulatory Research の Karen James 氏，Alison McGuire 氏に感謝申し 上げる.

利益相反＼cjkstart開示すべき利益相反はない.

\section{REFERENCES}

1) Yamamoto M., Matsuda T., Suka M., Furukawa A., Igarashi T., Sugimori H., Jpn. J. Soc. Pharm., 32, 8-17 (2013).

2) Yamamoto M., Furukawa A., Health and Labour Sciences Research Grant, "Research on the risk communication regarding information for safety measures with public and healthcare professionals," Report of fiscal year Heisei 23, 34-73 2012.

3) Yamamoto M., Furukawa A., Health and Labour Sciences Research Grant, "Research on the risk communication regarding information for safety measures with public and healthcare professionals," Report of fiscal year Heisei 24, 48-61 2013.

4) Yamamoto M., Doi H., Health and Labour Sciences Research Grant, "Investigation research on the risk communication related adverse reactions policy with public and healthcare professionals: Examination of the effective communication technique of adverse reactions, ' Report of fiscal year Heisei 25, 36642014. 
5) Yamamoto M., Health and Labour Sciences Research Grant, "Investigation research on the risk communication related adverse reactions policy with public and healthcare professionals: Examination of the effective communication technique of adverse reactions," Report of fiscal year Heisei 25, 7-35 2014.

6) Committee on Safety of Medicines Working Group on Patient Information, Medicines and Healthcare Products Regulatory Agency (MHRA). "Always Read The Leaflet: Getting the best information with every medicine," 2005: / http: / / www.mhra.gov.uk / home / groups / pl-a / documents / publication / con 2018041.pdf $\rangle$, cited 1 August, 2014.

7) Medicines and Healthcare Products Regulatory Agency (MHRA), Patient Information Quality Unit (PIQU) performance figures: 〈http://www.mhra.gov.uk/Howweregulate/ Medicines / Labelspatientinformationleafletsandpackaging / PIQUperformancefigures / > , cited 1 August, 2014.

8) "Kanjamuke Iyakuhin Guide Sakusei no Tebiki," Iyaku publication center, Tokyo, 2008.

9) Medicines and Healthcare Products Regulatory Agency (MHRA), Best Practice Guidance on Patient Information Leaflets (PIL Guidance): 〈http://www.mhra.gov.uk/home/ groups / pl-a / documents / websiteresources / con157151.pdf $\rangle$, cited 1 August, 2014.

10) European Medicines Agency, "Quality Review of Documents human product-information template version 8.3," 2013: 〈http://www. ema.europa.eu / ema/index.jsp?curl = pages / regulation/document_listing/document_listing_000134.jsp $\rangle$, cited 1 August, 2014.

11) Medicines and Healthcare Products Regulatory Agency (MHRA), Quality criteria for PILs: / http: // www.mhra.gov.uk / home / groups/is-insp/documents/websiteresources/ con2032836.pdf $\rangle$, cited 1 August, 2014.

12) Sless D., Wiseman R., "Writng about Medicines for People: Usability guidelines for consumer medicine information," 3rd ed., Communication Institute of Australia, Melbourne, 2006.

13) European Commission, A Guideline on the Readability of the Label and Package Leaflet of Medicinal Products for Human Use, 1998: 〈http: // pharma.be / assets / files / 854 / 854 128901376878944246.pdf $\rangle$, cited 1 August, 2014.

14) Medicines and Healthcare Products Regulatory Agency (MHRA), Guidance on the user testing of patient information leaflets, 2005: 〈http://www.mhra.gov.uk/home/groups/pla/ documents / publication/con1004417.pdf $\rangle$, cited 1 August, 2014.

15) Medicines and Healthcare Products Regulatory Agency (MHRA), Further guidance on designing patient information leaflets and how to achieve success in user testing, 2007: 〈http: // www.mhra.gov.uk / home / groups / pl-a/documents/websiteresources/con2030572. pdf $\rangle$, cited 1 August, 2014.

16) Sless D., Wiseman R., "Writing about Medicines for People: Usability guidelines for consumer medicine information," 2nd ed., Communication Institute of Australia, Melbourne, 1997.

17) Raynor D. K., Knapp P., Silcock J., Parkinson B., Feeney K., Patient Educ. Couns., 83, 404-410 (2011).

18) Knapp P., Wanklyn P., Raynor D. K., Waxman R., Int. J. Pharm. Pract., 18, 362-369 (2010).

19) Raynor D. K., Bryant D., BMJ Open, 18, e003185 (2013).

20) Raynor D. K., Res. Social Adm. Pharm., 9, 640-645 (2013). 